\title{
Learning by Doing: Reflections of the EPICS Program
}

\author{
Carla B. Zoltowski \\ EPICS Co-Director \\ Purdue University \\ West Lafayette, IN 47907 \\ cbz@purdue.edu
}

\author{
William C. Oakes \\ EPICS Director and Professor of Engineering Education \\ Purdue University \\ West Lafayette, IN 47907 \\ oakes@purdue.edu
}

\begin{abstract}
In this paper we describe the EPICS Program at Purdue that was started in 1995 and has evolved into a multidisciplinary academic program engaging more than 800 students per year from nearly 70 disciplines across and outside of engineering. EPICS has been disseminated to other campuses and has been adopted as a K12 approach for introducing engineering through community engagement. This paper describes the current program and shares best practices and lessons learned as the program developed to provide insight for faculty and administrators seeking to develop service-learning, learning through service-learning, or community-based engineering. Data from the program related to student learning and community impact is shared. A discussion of the characteristics to make dissemination successful is also discussed.
\end{abstract}

Index Terms - engineering community engagement, service-learning, design, human-centered design.

\section{INTRODUCTION}

The past several years have seen a dramatic increase in community engagement activities in engineering education. There has been a marked shift in the acceptance of the pedagogy of service-learning and community engagement within engineering as evidence points to how these experiences prepare students for careers in the private, public and non-profit sectors ${ }^{1,2}$. There is also growing evidence that community engagement can be a powerful tool in the efforts to eliminate underrepresentation within the engineering profession ${ }^{3}$.

Engagement is also being linked with other issues facing higher education including the value of a college degree as costs continue to rise. The recent Gallup-Purdue survey of more than 30,000 college graduates cited experiences, especially long-term experiences as providing some of some of the highest value during their college years ${ }^{4}$. Engagement experiences that span multiple semesters or even years provide these high value added experiences during the college years.

As the number of community engagement efforts increase, it is important that we learn from the lessons and best practices of others so that we can ensure that our efforts are positively benefitting all of the stakeholders. This paper is part of a larger effort to share such best practices and lessons learned. The paper is written from our perspective as we enter our 19th year of offering a service-learning design program. Our program continues to develop as we learn and incorporate the best practices from within our engagement community. The needs of today's world are enormous and the opportunities for technology-based solutions abound. We seek to make a difference in our community and in our world. We want to share our story and look forward to reading the stories of others. 


\section{Brief baCkground ANd History of Program}

The EPICS (Engineering Projects in Community Service) Program began at Purdue University in 1995. It was founded by Professors Leah Jamieson and Edward Coyle in the School of Electrical and Computer Engineering (ECE) because of feedback from industry that students were not adequately prepared for the transition into professional careers ${ }^{5}$. Originally Jamieson and Coyle pursued corporate projects for this initiative, but recognized the wonderful opportunities that partnering with community organizations offered when they saw the request for proposals from the U.S. Department of Education's Fund for the Improvement of Postsecondary Education (FIPSE) program. In the preparation for that grant, they attended a meeting of the local United Way agencies (a collection of service agencies in the local community) to present their concept of an engineering service-learning program. They presented an initial project idea and returned with more than 20 other ideas for projects from that first meeting. The grant was successful and launched the EPICS Program.

During the first semester, 40 senior-level ECE students were registered, working on five project teams with support from one graduate teaching assistant. After the first semester, the course began attracting students from other majors to the projects, as well as juniors. Students heard about the class from their volunteer work at the partnering agencies as well as from their friends in the class. Shortly after, a second grant was secured from the Learn and Serve American program within the Corporation for National and Community Service. At that time, Profs. Jamieson and Coyle were not familiar with service-learning pedagogy or the large servicelearning community that existed outside of engineering. Their first meeting as part of the Learn and Serve program introduced them to this larger community.

The program grew steadily, and by 2002-2003, it had 24 teams and over 300 students from 20 different departments (Coyle, Jamieson \& Oakes, 2005). At that time, we described projects has having five phases: establishing project partners, assembling a project team, developing a project proposal, system design and development, and system deployment and support. Today, as indicated later in the paper, the projects are guided by the EPICS Design process which consists of seven phases: Project Identification, Specification Development, Conceptual Design, Detailed Design, Delivery, Service/Maintenance, Redesign/Retirement.

Since EPICS began in 1995, it has received support by grants from the U.S. Department of Education's Fund for the Improvement of Postsecondary Education, the National Science Foundation's Instrumentation and Laboratory Improvement Program, the Corporation for National Service Learn and Serve America Higher Education Program, the National Science Foundation (NSF) Action Agenda for Engineering Curriculum Innovation Program, the NSF CCLI National Dissemination Program.

The operation of the program has not been supported by federal grants for the last ten years. Funding comes from a combination of university funds and by grants and donations from numerous companies and foundations, including National Instruments, HP, Intel, Microsoft, Air Products, Alcoa, Boeing, Caterpillar, Eli Lilly, GM, GKN Sinter Metals, Motorola Solutions, Rockwell Collins, Rolls Royce, Schneider Electric, Shell, TRW, and Wabash National. Individuals, including the family of William Corcoran and Charles and Ana Mae Miller, have established endowments that provide partial support for the program. EPICS has been recognized by the NAE with the Bernard M. Gordon Prize for Innovation in Engineering and Technology Education (2004); as an NAE exemplar of programs "Infusing Real World Experiences into Engineering Education (2012); by the NSF Corporate Foundation Alliance as 
an Exemplar Program (2002); the Associate of Public and Land Grant Universities as an Exemplar of Engagement, by Campus Compact with the Thomas Ehrlich Award, and by the American Society for Engineering Education with the Chester Carlson Award for Innovation in Engineering Education (1997 and 2012). In 2013, IEEE recognized EPICS as a signature program.

The EPICS has been disseminated to other universities and colleges with 23 programs currently active. Based on this success and motivated by the need to open more pathways to students early-on, the EPICS High program was first piloted by two alumnae in $2004^{6}$. In 2007 with support from Learn and Serve America, EPICS launched a multi-state expansion of EPICS High. Currently, more than 50 high and middle schools in 11 states within the U.S. have EPICS programs with an additional 30+ abroad through a partnership with $\mathrm{IEEE}^{7}$. Although there are core values or characteristics all EPICS programs are expected to meet, there is considerable variation in each of the programs, based on how long they have been in place as well as institutional culture. For this paper, we will describe how the EPICS Program has evolved at Purdue University over the last 19 years.

\section{DESCRIPTION OF CURRENT PROGRAM}

The EPICS Program at Purdue University is a multidisciplinary, vertically-integrated, studentled, service-learning design course. EPICS students can participate multiple semesters; teams include first-year through senior students, and typically have a mix of returning and new students on the team. Students take on different roles, such as project manager, design lead, and project partner liaison, and the students and team are mentored by advisors (faculty, professional staff from Purdue and local industry). EPICS has grown at Purdue to 32 divisions with a total of over 400 students each semester (and over 800 for an academic year). Each division is broken down into project teams that are typically 4-6 students. Students enrolled come from more than 70 majors that represent all of the colleges within the university. With its focus on engineering in context and strong emphasis on teamwork, communication, and commitment, EPICS is also proving to be an especially effective vehicle for encouraging women and under-represented groups in engineering. In the spring of 2014, $29.9 \%$ of the engineering participants were female compared with $21.7 \%$ for the college as a whole, while $46.7 \%$ of the participants were nonCaucasian compared to $40.6 \%$ for the college. At Purdue, we use the acronym (EPICS), and not the original full name, when advertising and recruiting for the program. We have done this because we have found that having the word "Engineering" in the program title can deter students from outside of engineering from participating and we want students from all over campus to feel welcome to take the course. In addition, the words "community service" imply to some faculty that the activities are non-curricular.

Since the beginning, the focus has been on long-term partnerships with community organizations versus semester-by-semester projects. In addition, EPICS decouples the student learning, academic calendar, and the project timelines. In traditional courses, the student learning is tied to the academic calendar as shown in Figure 1. This is the same for many project classes, where students have to begin at the same point of the project (often the same project), and reach the same ending, and typically within one academic term. 


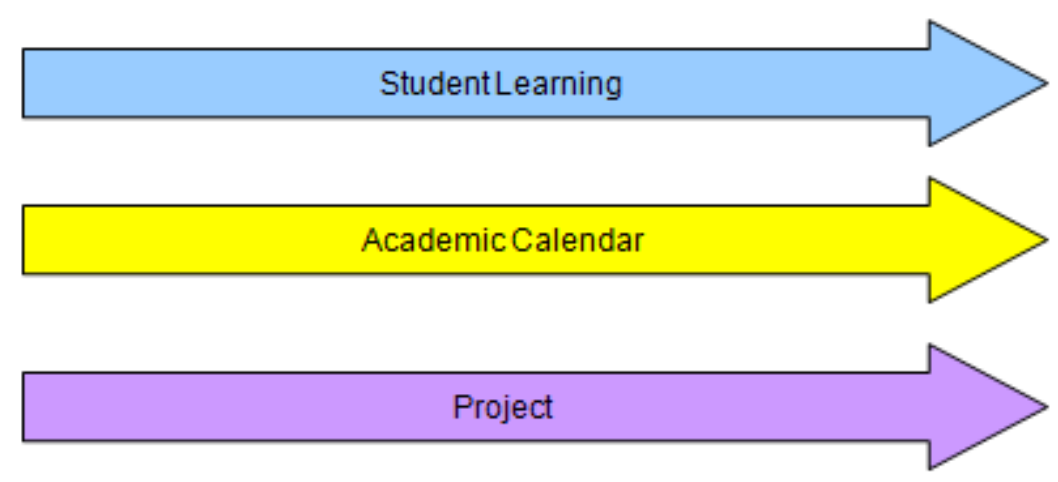

FIGURE 1

TYPICAL ALIGNMENT OF ACADEMIC, PROJECT, AND STUDENT LEARNING TIMELINES

However, in EPICS, the timelines are decoupled (see Figure 2), so that projects can extend beyond one academic term. This allows us to scope projects to meet the needs of the community partner, not the requirements of the academic timeline. It allows for iteration within the design process as problems and improvements are identified. In addition, students can participate in multiple semesters. To encourage this, the EPICS courses are one or two credit hours, whereas a typical course EPICS is used to substitute for (e.g. technical elective) is three credit hours. These returning students often take on increased leadership responsibilities each semester and provide continuity to the projects. These aspects together allow us to facilitate long-term partnerships with our community partners and provide the long-term support they need.

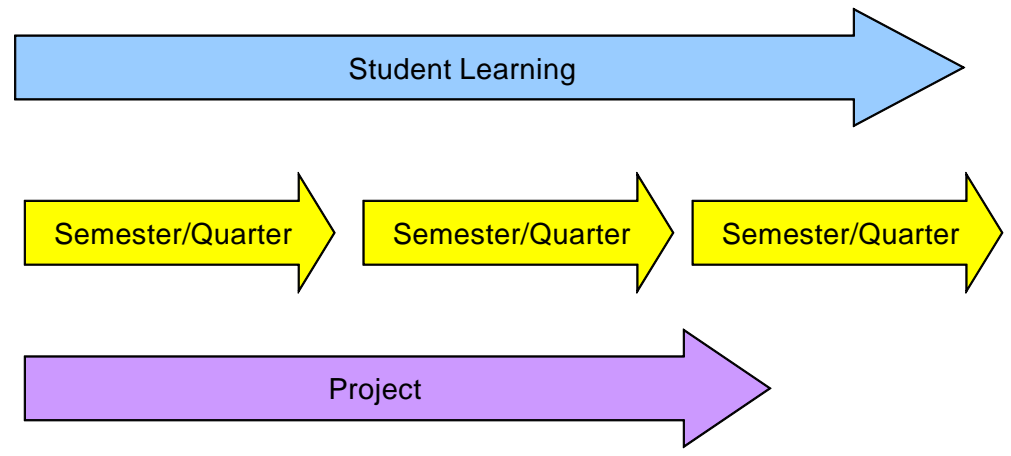

FIGURE 2

EPICS DECOUPLES THE ACADEMIC, PROJECT, AND STUDENT LEARNING TIMELINES

\section{Dedicated Course Numbers}

EPICS was initially offered under a few ECE courses numbers and as other disciplines (Mechanical Engineering, Civil Engineering, and Sociology) began to participate, they would establish their own course numbers. However, students from one particular course number did not meet together. Instead, each course had several section/division numbers that corresponded to a particular partnership, or team, in EPICS, which were scheduled to meet together. In 2003, 
EPICS became its own academic program within the College of Engineering with its own course numbers. There are different course numbers for each year (first-year, sophomore, junior, and senior) and number of credit hours (one or two credits), as well as unique course numbers for capstone design and the first-year learning community.

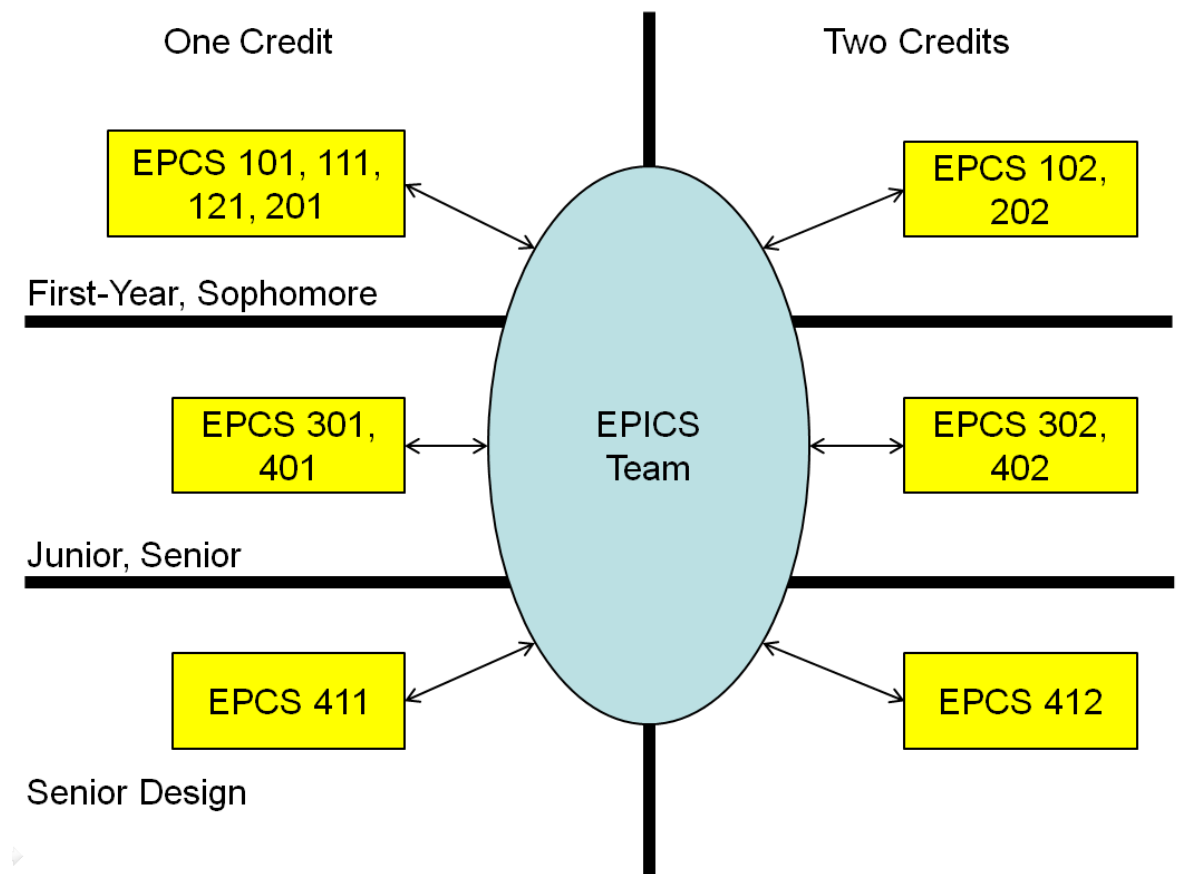

FIGURE 3

COURSE STRUCTURE OF PURDUE EPICS PROGRAM

Each department, program, or school determines how EPICS counts in their curriculum. For all of the engineering disciplines at Purdue, EPICS courses will satisfy a technical elective (although some only allow upper level courses). The EPICS leadership has worked with various curriculum committees to share our outcomes and discuss the assessment processes. In some cases, we had to adjust our processes but in most cases we aligned with their goals. EPICS courses are also options to satisfy the capstone requirement in Electrical and Computer Engineering, Multi-disciplinary Engineering, and Ecological and Environmental Engineering. In each of these cases, assessment data is collected for accreditation reviews. EPICS has participated successfully in three rounds of ABET reviews as a capstone option. EPICS courses can be used to satisfy the option and capstone requirements of the Entrepreneurship Certificate, Science, Technology \& Society outcome of the Purdue Common Core requirement, and the experiential component of Engineering Leadership Minor. The EPICS Program has established outcomes that have been agreed to by the departments and colleges so that students do not need to petition for these substitutions. Furthermore, EPICS has been included in many research proposals from CAREER awards to large center proposals as an education, outreach and diversity component. Efforts are made to integrate the program into as many of the university's initiatives as practical. 
A curriculum committee comprised of 12-15 faculty from different departments and schools within and outside of engineering oversees the courses and has responsibility to approve any changes to the curriculum As EPICS has evolved into its own program, there has been an intentional effort to use the same processes, such as curriculum committees, to establish credibility within the institution. While it slows things down sometimes, it helps to institutionalize the program and provide curricular credibility.

In 2007, we began offering an EPICS Learning Community (LC) option for first-year engineering students. The EPICS LC consists of three courses together (first-year engineering course, an EPICS course, and a communications or English course), as well as optional residential component. These students were integrated with sophomores, juniors and seniors in the EPICS course and currently account for 120 of the enrolled students. Initially, the EPICS course was taken as an elective course as part of the learning community. Many students were not able to continue in EPICS the second semester because of the already packed curriculum. So in 2012, an alternate sequence through the first-year was approved in which students took a special condensed first year course and used two semesters of EPICS as part of their first-year requirement. This maintained a total of four credits in the first year for engineering and also allowed students to have a two semester experience with engineering. It was the first alternate path for first-year engineering at Purdue for students outside of the honors program. The demand for the EPICS LC, which is limited to only first-year engineering students, has quickly increased and provided evidence of the importance of context for underrepresented populations. Students apply for a learning community once they are accepted into the university and are selected using a holistic process by a centralized university learning community committee. In 2014, more than 380 students applied for the 120 EPICS LC spots and 54\% of the class is female.

We found the learning community is an important structure for first-year students in the vertically integrated teams. In the current configuration, no student has indicated that they wished they had not participated in EPICS LC and had done the traditional track. Prior to the learning community, the experience of the first-year students was bimodal. It was either very positive or very negative and depended a great deal on how well they were integrated into their vertically integrated team. The learning community provides spaces where students feel supported and can discuss challenges within their EPICS teams. Also, as more students have gone through the learning community, teams have learned how to better integrate the first year students into the team ${ }^{8}$

\section{Course Structure}

There are both lecture and lab components of the courses. The lecture component consists of a few traditional lectures, as well as interactive learning sessions we call "skill sessions". Both the lectures and skill sessions are common across the different courses and labs. The lab component provides the structure for the specific project work for the teams, meeting for two hours each week. The labs are led by students and typically begin with each project team reporting on their progress, the issues they encountered during the week and their goals for the coming week. The faculty or industry advisors (instructors), TAs, and students can ask questions, provide suggestions, and identify follow-up items based on the team status report. The majority of the lab time is spent working with the advisor(s) and TAs with individual teams. 
The course learning outcomes are as follows:

- Discipline Knowledge: ability to apply material from their discipline to the design of community-based projects

- Design Process: an understanding of design as a start-to-finish process

- Lifelong Learning: an ability to identify and acquire new knowledge as a part of the problem solving/design process

- Customer Awareness: an awareness of the customer

- Teamwork: an ability to function on multidisciplinary teams and an appreciation for the contributions from individuals from multiple disciplines

- Communication: an ability to communicate effectively both orally and written with widely-varying backgrounds

- Ethics : an awareness of professional ethics and responsibility

- Social Context: an appreciation of the role that their discipline can play in social contexts

\section{EPICS Design Process}

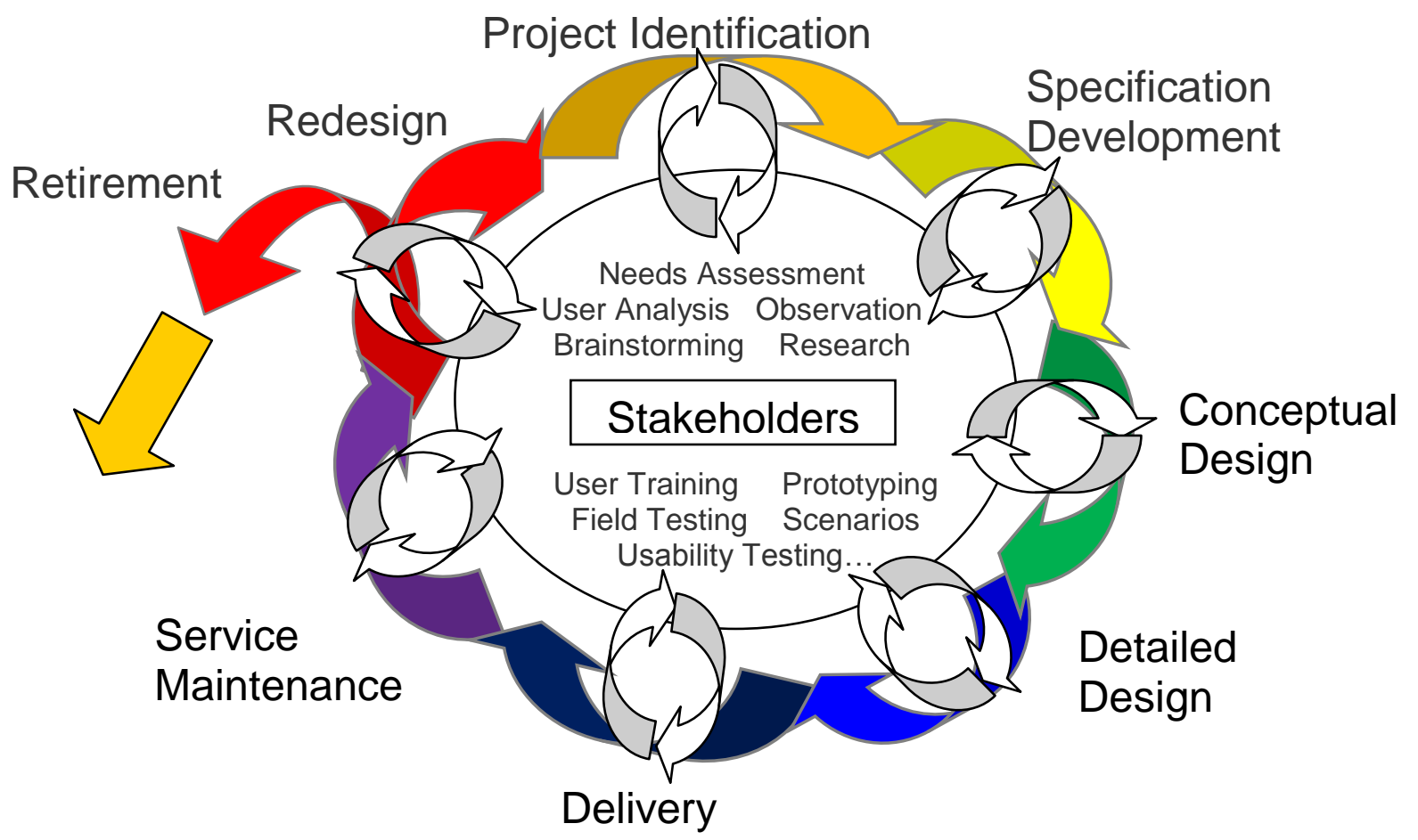

FIGURE 4

EPICS DESIGN PROCESS MODEL

Recognizing there is not a single model for design, EPICS did not initially teach a specific design process. Students learned different design processes in different majors and were asked to use those. It was observed, however, that not all students were learning any design process model nor were most teams using a formal design process. A change was made to teach a single design 
process that would be applicable for community-based designs. The EPICS design process was developed to reflect a human-centered approach where stakeholders are at the heart of the EPICS design process (Figure 4). Stakeholders encompass all of those who are impacted by the project including the direct users, the community partner organization, secondary users such as teachers, therapists, and people who maintain the project, parents and family members, as well as the broader communities that each of these stakeholders represent. The EPICS design process begins with understanding the needs of the stakeholders and involves them throughout the design process. It is iterative and advocates the use of prototypes and empirical evaluation to make design decisions. It also includes attention to the delivery, service, and maintenance aspects of the project.

Although the overall goal is to move through the phases, sometimes the project team gains new knowledge about the requirements, constraints, users, context, usability and/or capabilities of technologies being used that make it necessary to iterate, or go back to previous phase and complete it again. However, there are a couple of points in the design process that are "go vs. nogo" decision points that require an agreement from the project partner, advisors, and/or EPICS administration to go forward with the design. They are indicated as "Gates" in the design process. The use of "Gates" is very common in industry, where meeting certain criteria is required to gain additional resources in the development of the product.

The move to a common design process has been very positive. The results of students being more aware of design is noted in the programmatic assessment section later in this paper. A common model across all teams has also made design reviews more uniform. Industry volunteers review each team's designs twice per semester and these volunteers often review over multiple teams. A common design process has facilitated effective critiques across teams.

\section{Lab Division = Team}

Each lab division, or team, has its own internal structure. Students select the teams through the registration system; we do not assign students to teams. Thus, the number and composition of the team varies each semester, but is typically $10-24$ students. The teams are predominately run by a student selected from among the members of the team; originally this role was referred to as the "team leader." However, it has been renamed "Project Manager" to better align with their responsibilities and with industry use and understanding of such a role as having responsibility for managing the resources of the team and meeting deadlines. In addition, this shift reflects our concern about the length of time some teams take to deliver a project. Designers tend to want to continually iterate and improve the design and a project manager is needed to keep the team on track to deliver the project in order to provide service to the community. Figure 5 shows a diagram outlining the structure of an EPICS team: 


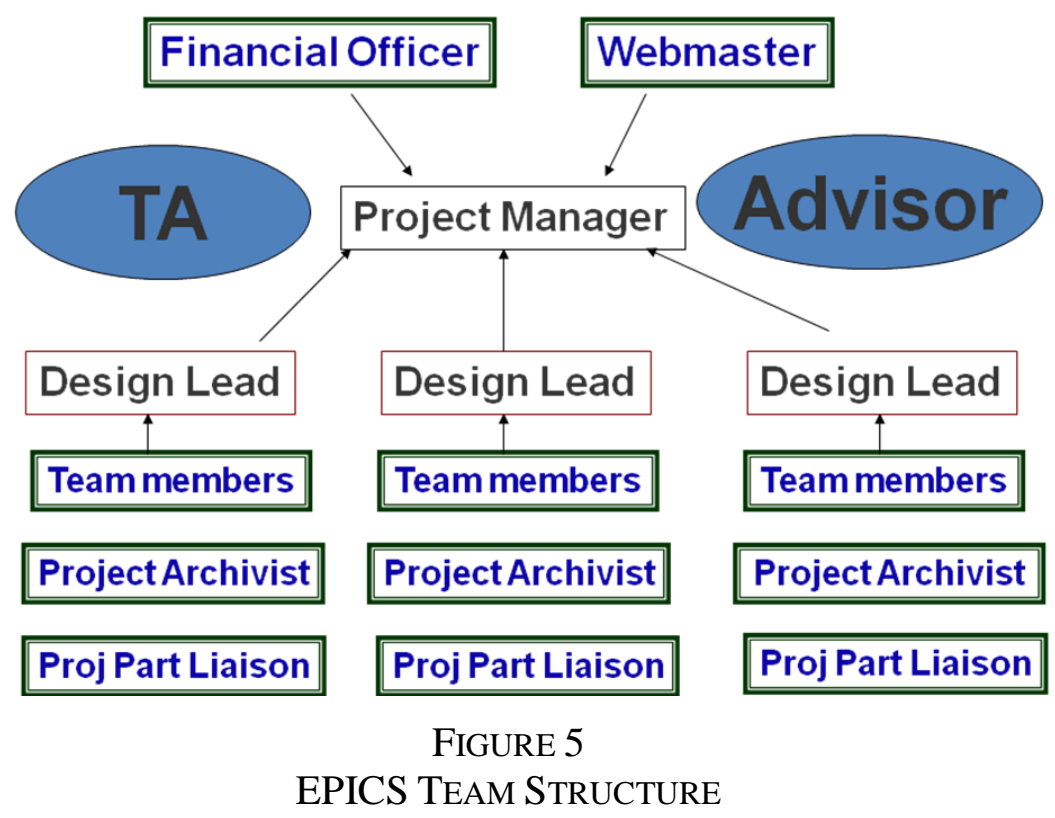

Another formal role is the Design Lead (or Project Leader), who oversees the project design and is responsible for facilitating the project through all aspects of the design process, including project identification, needs assessment, conceptual and detailed design, testing, and delivery. The Project Partner Liaison oversees and manages all communication between the team and the project partner and other stakeholders. In some teams, all of the projects have the same community partner and the lab section only has one project liaison. The Project Archivist is responsible for making sure that the project team is documenting the work being done throughout the semester. Each team also has a Webmaster who is responsible for updating and maintaining the team's website per the program's requirements. Although there are components that are required, each team has the flexibility to modify the website to reflect their context and team need. The websites are important for communicating internally and with external audiences. Often corporate sponsors will indicated that they have viewed the websites before meeting with our program to discuss sponsorships.

Another leadership position is the Financial Officer who is responsible for developing and managing the team's budget. The overall program has a budget that comes from corporate donations and each team submits an annual budget each fall based on their needs for the year.The amount varies by team and year, and approved by EPICS administration based on comprehensive review of all of the needs within the available resources. Once funds are allocated to teams, the Financial Officer is responsible for managing the team's budget.

Each team has its own processes for assigning students to teams and selecting students for team roles. However, one common practice is ask student to indicate their preferences for teams and roles, and then the advisors and TAs review and make assignments to optimize student preferences as well as ensuring that teams are balanced and have the skills and experiences needed to be successful. The student roles not only provide a great experience for the students, but contribute to sustainability of the program. Students take on many activities that faculty in other community engagement courses typically manage. 
The faculty, staff and industry instructors serve as "advisors" for the team, meeting with the team weekly providing feedback and asking questions to keep students on track. They also have responsibility for grading the members of the team. At Purdue, advisors come from faculty, university staff personnel, and local industry, often assigning co-advisors from complementary disciplines. The Teaching Assistants, or TAs, provide technical guidance to supplement background of advisors and administrative assistance for operation of program. Although one TA is assigned to each team, they together provide a talent pool for all of the teams in EPICS. TAs hold office hours and conduct skill sessions as needed for the students. In addition, they provide do initial grading of the notebooks, reflections, etc., for the advisors. In 2014 there are 11 graduate TA's and 43 advisors (17 faculty, 17 staff/instructors/graduate fellows and 9 community or corporate volunteers). The teaching load has been examined within the engineering schools/departments and based on the student credit hours and faculty time, it has been determined to be equivalent to half a traditional 3 credit course. This works well with our model as faculty are committed for two semesters for their teaching credit.

The role of the administrative staff at Purdue is to provide program planning, development, management, and oversight, course management, community partner identification and selection; resource management (funds, labs, staff), and assessment and data collection and reporting.

\section{Lectures and Other Resources}

The lecture component of the course consists of both traditional lectures as well as more interactive workshops which we call skill sessions. The lectures and skill sessions are designed to meet the needs of both new and returning EPICS students, students from different levels and disciplines, one and two-credit hour students, as well as very diverse projects. Students are required to participate in five lectures or skill sessions if taking EPICS for one credit, and ten lectures or skill sessions if taking EPICS for two credit hours.

The lectures occur in conjunction with the lab portion of the course, not prior to the project work. Most lectures videotaped are to accommodate lecture conflicts, wich is important for broad base, returning students. In their first semester of taking the EPICS courses, there are five required lectures that they attend which cover human-centered design and ethics. In subsequent semesters, they can select from a list of lectures, skill sessions and workshops which explore aspects of design, project management, and leadership. Example skill sessions include CAD tools, microprocessor programming, energy modeling software, using hand tools, and soldering. The concept is similar to professional development hours required for professional engineers but there is a requirement for each semester. Each advisor (instructor) can approve alternative activities to count for this requirement too. We are currently working to move many of the lectures and skill sessions online so that they are more readily available to the students when they need them in their projects, and allow the TAs to provide more support in implementing them in their projects.

\section{Design Reviews}

Each EPICS team completes two design reviews by reviewers external to the team each semester, one at mid-semester and one at the end of the semester. Not only is this a great professional experience for the students, it helps our program to ensure that the projects we are 
designing and delivering to the community are safe, appropriate, and sustainable and to get feedback on projects. EPICS administration invites externally reviewers who often review several teams during the day; in addition, each team invite reviewers who are relevant to their projects (e.g., someone with specific expertise, project partner, expert). Teams must prepare documentation prior to the review to send to the reviewers. After the review, teams are responsible for documenting what issues were raised and how they were addressed.

\section{Reflection}

Critical thinking/reflection is an important part of learning, and of design. Students are expected to write reflections regularly in the course. This is encouraged through weekly prompt questions during lab/lecture where students write for three to five minutes in their lab notebook, as well as the following guide questions 9 :

- What did I learn?

- How did I learn it?

- Why does this learning matter?

- What will/could I or others do in light of this learning?

Discussions during the lab time are often led by the advisors in regards to the community partner and the projects. These most typically occur before or after a visit or interaction with the project partner(s) or around the twice a semester design review.

In addition, students complete a final reflection at the end of the semester. In the final reflection, students are asked to critically reflect (300 words each) about what they have learned in two of the following four areas ${ }^{9}$ :

- Personal and Professional Development: What did you learn about who you are (your strengths, weaknesses, assumptions, skills, convictions, etc.) and who you want to become, personally or professionally?

- Social Impact: What did you learn about the broader impacts of your work and how you and others can affect change locally and/or globally? What did you learn about the community, the needs, and/or the quality of the service provided?

- Academic Enhancement: What did you learn related to your discipline and how was that enhanced by the service-learning context? What did you learn about Human-Centered Design?

- Ethics: What you have learned about professional ethics, the ethical issues you encountered in your team and your project, and how decisions regarding ethical issues are made individually and as a team?

\section{Student and Project Assessment}

A significant challenge for EPICS to assess individuals is the variability in students who come from first-year to senior and from about 70 majors with different expertise and experiences to bring to the project. And since we decouple the project timelines from the academic calendar, students may start the semester with a new project or they can be picking up a project that was not completed in the previous semester. Therefore, we use an assessment process that is modeled 
after the performance appraisal systems used in the corporate world to individualize each student's assessment. The first step in the assessment process is for students to establish their goals and expectations for the semester in consultation with the faculty member who oversees that section of EPICS. This is done at the start of the semester as teams are developing their semester plans for the project. The concept is that the project plans set the expectations for the teams and the goals set the expectations for the individuals. Once the goals have been determined, progress toward the goals is documented and evaluated with the Individual Evaluation Rubric, a document which summarizes the students' learning and accomplishments, and the evidence of such. The Individual Evaluation Rubric is shown in Appendix A; more information and the overall assessment process for EPICS is described by Cummings, Zoltowski, Huff, and Oakes ${ }^{10}$.

As evidence for the assessment, EPICS utilizes authentic individual and team artifacts such as notebooks, blogs, final reflection, lecture and lab attendance, electronic portfolios, design review presentations and feedback, project partner communication and feedback, design documents, and the project itself. In addition, the Individual Evaluation Rubric allows students to conduct a self-assessment which allows them to receive feedback on their work, thinking and learning as well as their ability to self-evaluate. Rubrics are provided that describe what is needed for each grade. They are based on the ABET language but with "engineering" replaced by "your discipline" and "technical" with "disciplinary". This allows each student to read into his or her expertise and be evaluated against the criteria. Finally, Peer Evaluation and Feedback are also done for each student in each team. They include self-evaluation and anonymous evaluations from peers that are used to supplement the individual documentation.

In addition to the individual assessment, we have incorporated project level evaluation rubric. This was added when we recognized that we needed a more formal and consistent way of evaluating the projects and the project team. This is an important aspect to consider, especially in community engagement courses when the impact of the individual efforts have a larger purpose--positively benefitting the community. Project level artifacts include prototypes, demos, and completed projects which are evaluated by the instructor as well as design reviewers from industry and the community. Community Partners also evaluate the teams and provide feedback on their communication, quality of work and the quality of the projects.

The advisors of the teams are responsible for assigning grades based on a comprehensive evaluation of the work completed by both the individual and the project team. Most advisors do not assign specific points to assignments, but do a holistic review of the evidence provided using the grading rubrics to determine the grades. We recommend some heuristics, such as comparing the average individual grade of team members to the overall team grade, to make sure the evaluations are consistent. This is done to allow accommodation for the variety of projects, phase of the designs and the diversity of students. Advisors in the past who have used point systems have found that students optimize to the grading scheme, which can have unintended consequences. For example, advisors who gave extra points for delivering a project found that the students began to scope projects so they could be completed in one semester, and avoided larger projects that the community partner needed because they could not be completed and delivered in one semester. The intent is to value work that is valued by the community partner and to allow students to demonstrate excellence. The system empowers students to show excellence in a variety of ways and has been cited by alumni as preparing them for performance appraisals where this no point system but a need to justify value for the company each year. 


\section{Capstone Design}

EPICS projects are well-matched to the ABET criteria. However, the customer-driven servicelearning means that each team has a different project and that each student may have a different role on the team.

This variability requires procedures for assessment, tracking, and documentation of projects and of student outcomes. The student outcomes are the same for the senior students; however, students must satisfy all eight of the outcomes at a senior level to meet ABET requirements ${ }^{11}$. Typically, the capstone design experience is two semester, although we are planning on piloting a one semester capstone design experience which requires prior participation in EPICS. Three documents are used track progress/completion:

1. Project Proposal: Individual document that provides early feedback on project appropriateness (Significant design experience on a suitable project)

2. Outcomes Matrix: Individual document that demonstrates all outcomes were met over the two semester experience

3. Project Description: Common document required by ECE, adopted by other departments, to describe how project teams have met outcomes

The assessment process is similar to non-senior design students, using authentic artifacts such as the project deliverables, design notebook, design reports, presentations, customer feedback, and peer evaluation as evidence to determine and document whether all outcomes have been satisfied using the three documents above to summarize and index the work completed. However, there is a specific rubric used to evaluate the senior design students. An example for the first outcome is given in Table 1.

TABLE 1

SAMPLE CAPSTONE RUBRIC FOR AN OUTCOME

\begin{tabular}{|l|l|}
\hline Outcome: i. applies material from their discipline to the design of community-based projects \\
\hline Excellent (A) & $\begin{array}{l}\text { Readily identifies the relevant principles \& develops elegant models to apply to their design. } \\
\text { Consistently solves problems elegantly \& correctly. Excellent at prediction and provides clear } \\
\text { explanations of effects. Excellent understanding and clear explanations of disciplinary concepts. } \\
\text { Sees the fundamental nature of novel problems and correctly applies knowledge }\end{array}$ \\
\hline $\begin{array}{l}\text { Adequate - } \\
\text { Good (C/B) }\end{array}$ & $\begin{array}{l}\text { May include extraneous principles, but ultimately finds correct ones and develops model(s) to } \\
\text { apply to their designs. Answers often correct, but may have minor errors. Uses non-optimum } \\
\text { strategies. Usually predicts impacts of parameters correctly and explains effects. Reasonably } \\
\text { good understanding of disciplinary concepts. Can often explain, but may resort to jargon. } \\
\text { Usually sees how to apply disciplinary knowledge to new situations, although may need help. }\end{array}$ \\
\hline Marginal (D) & $\begin{array}{l}\text { Have difficulty deciding what principles to use, but may develop a close to correct model to } \\
\text { apply to their design. Has some difficulty solving equations; frequent errors, problems often } \\
\text { partially solved. Difficulty predicting parameter effects on the design. Some understanding of } \\
\text { disciplinary concepts, but has to resort to jargon to explain. If the situation is not too novel, } \\
\text { occasionally sees application of knowledge \& may apply correctly. }\end{array}$ \\
\hline Unacceptable (F) & $\begin{array}{l}\text { Cannot identify relevant principles or develop models to apply to their design. Not able to } \\
\text { predict or understand parameter effects on the design. Does not understand phenomena and } \\
\text { cannot explain. Unable to transfer knowledge from their disciplinary courses to new situations. }\end{array}$ \\
\hline
\end{tabular}


The Project Proposal, Outcome Matrix, and Project Description are approved by the advisor as part of the grading process, and then each semester the advisor-approved documents and the process are reviewed by EPICS administrators or representatives from the discipline communicate with the advisors for continual improvement and provide assistance for the assessment when appropriate. EPICS has been part of three ABET reviews and each time has been cited as a positive within the programs that allow EPICS as a capstone. The work and success was a contributing factor to EPICS being invited to conduct a workshop at the annual ABET meeting in 2014.

\section{Managing Multi-semester Projects}

Multi-semester projects require structures different from most courses to allow transitioning and access to resources from one semester to another. Many current course management systems did not facilitate students from one semester to access past reports, etc. At one point we had students post all of the relevant information on their public websites. However, we moved to using a password protected file share system so that teams wanting to patent their work would not have to publicly disclose details of their work in this way. Now, we use a document management system for resources for all teams. In addition, each team has a site within the system that they use to post their team and project documentation and information for current and future team members. Students in EPICS are able to search the entire site to facilitate sharing of information and resources across all of the teams. In order to address ongoing issues with documentation quality, we have created a position, the project archivist, whose responsibility is the documentation to continue to improve. Finally, attention to transitioning to the next semester is explicitly part of the course schedule and discourse.

\section{Developing and Maintaining Community Partnerships}

EPICS uses a multi-layered approach to developing and maintaining community partner relationships. As a result, EPICS has been able to maintain partnerships for many years, with two of the original partners from 1995 still active. The main way this is done is through relationship building. Most initial contacts with community organizations are made by EPICS administration. We have a web form that potential project partners can complete if they are interested in partnering, but many initial contacts come from faculty, staff, and students. The long-term relationships and partnerships are formalized through a Memo of Understanding (MOU) and "Hold Harmless Agreement" for an initial five year period (current versions of the document can be found on the EPICS website, www.purdue.edu/epics). Once the EPICS team begins, the team and the advisors begin to take responsibility for the relationship, typically through the project partner liaison. Advisors also seek the input from the partners each semester as part of the grading process on the work and communication with the teams. In addition, we intentionally have staff whom are not part of the grading process talk with the partners periodically to see if there are any challenges. Students and teams often communicate with their community partner contact via email, phone, Skype, and visits. Interactions with community partners are expected throughout project.

Maintainability and support are included as part of the design process. Discussions of roles of both community partners and EPICS are part of delivery process. In addition, one responsibility 
of the team is to check on projects still deployed in the field to see if they require any maintenance or if they are still needed and teams often bring back projects from the field for maintenance or redesign. Upon delivery, community partners complete a delivered project evaluation form. Since the MOU was signed at the start of the partnership that included liability, no further forms are signed on delivery.

Projects are provided to our community partners without obligation for remuneration to EPICS. For most projects, EPICS assumes all of the project material and development costs which is made possible through the generous support of our team sponsors. Some of the more expensive projects, like building a more energy-efficient Habitat for Humanity home, are supported by external grants. The costs to maintain the project are usually bore by the community partner. In addition, the community partner shares in the costs through their insurance policies.

\section{Local and Global Partnerships}

When EPICS first began, we only partnered with local community organizations. One reason was pedagogical as frequent access to the user/project partner/customer was important for learning design and the ability to obtain feedback and iterate. Local projects also offered ease of access as students could drive to the partners during the two hour lab. Furthermore, research suggests that "critical experiences", where design assumptions are challenged, facilitate more comprehensive ways of understanding human-centered design ${ }^{12}$. We also wanted students to be able to connect to issues in their local communities. We believed that if they could see needs in their local community, they could also make connections to needs in global areas of need. Interactions between the students and project partners varied, but typically the teams interacted with their community partners at least once a month either by site visits, visits to campus, emails, or phone calls.

As the program evolved, EPICS began to work on global projects because of the need of one of our community partners, Habitat for Humanity. The local affiliate is associated with an affiliate in Haiti and asked our team to help develop more sustainable building practices, as well as address disaster housing issues after the earthquake. The number of global projects has increased recently as a result of increased student interest in global projects, increased number of international university partners as part of the EPICS university consortium, initiatives on campus to support study abroad, and a goal that all engineering graduates are globally competent.

One thing we have learned is that we were not originally equipped to manage nor had funding models in place to facilitate the global student trips. This made it difficult for the student teams to make progress and the students did not have the opportunity to have their assumptions challenged. We have begun to partner with the Global Engineering Program to leverage their expertise in supporting the travel, etc. Although we do not have a formal "community assessment trip", we are facilitating student travel to visit our global partners by leveraging annual short-term study abroad experiences. The university provides scholarships for all students to participate in these, but does require students to fund a portion of the trip. And although our design process emphasizes an awareness of cultural, social and contextual issues, we are utilizing resources and opportunities on campus to develop specific cultural, social, and contextual knowledge for the global teams. Situating global projects in EPICS has been beneficial for 
developing and maintaining our global community partnerships as it provides a structure for continued work and support of the project during the academic year in between trips. Our corporate sponsors have been supportive of expanding global experiences for our students.

The alignment of the curricular model of EPICS and global engagement has expanded our partnership with academic and student organizations within the university. Faculty who have been leading global projects from within engineering and from other colleges have collaborated to explore and implement new EPICS sections that integrate their global engagement with EPICS. One example is a program led by faculty from Agriculture in Haiti. A faculty member in Animal Sciences leads an annual trip to Haiti with EPICS courses running year round to support the projects. An example project is a poultry facility that is designed by the animal science and engineering students and will be powered by a solar power system designed by engineering students. Another section is integrating the Purdue EWB-USA chapter into an EPICS class while still allowing students to participate in the student organization. The pilot of this course was started in the fall semester of 2014. The addition of the global projects has added to the topics of the lectures and skill sessions. As noted earlier, we have heavily leveraged the existing activities and infrastructure for these activities.

\section{EPICS Organization}

When EPICS started, there were 40 students distributed on these five lab sections and one graduate teaching assistant. The initial Co-Directors were Profs. Jamieson and Coyle, who were full professors in ECE. They both managed the program as it developed, as well as maintaining active research programs. As the program expanded, an administrative assistant was added to the program. This person was able to work with the community partners and manage the logistics with the students related to courses (adding, dropping, getting into the right sections) and purchasing. Designing real and diverse projects for the community necessitates making many purchases and it requires someone to help manage those tasks. This administrative position, shown in Figure 6 as the program coordinator, has grown in responsibility but is still in the organization of the program. Administrative support has been a key component for programs growing at Purdue and other institutions. Professor William Oakes was added as a third codirector in January of 1998 as Prof. Coyle went special assignment with the office of vicepresident for research. At this time, the EPICS Consortium was started to disseminate the model of EPICS. In the early days it was called the EPICS National Program. 


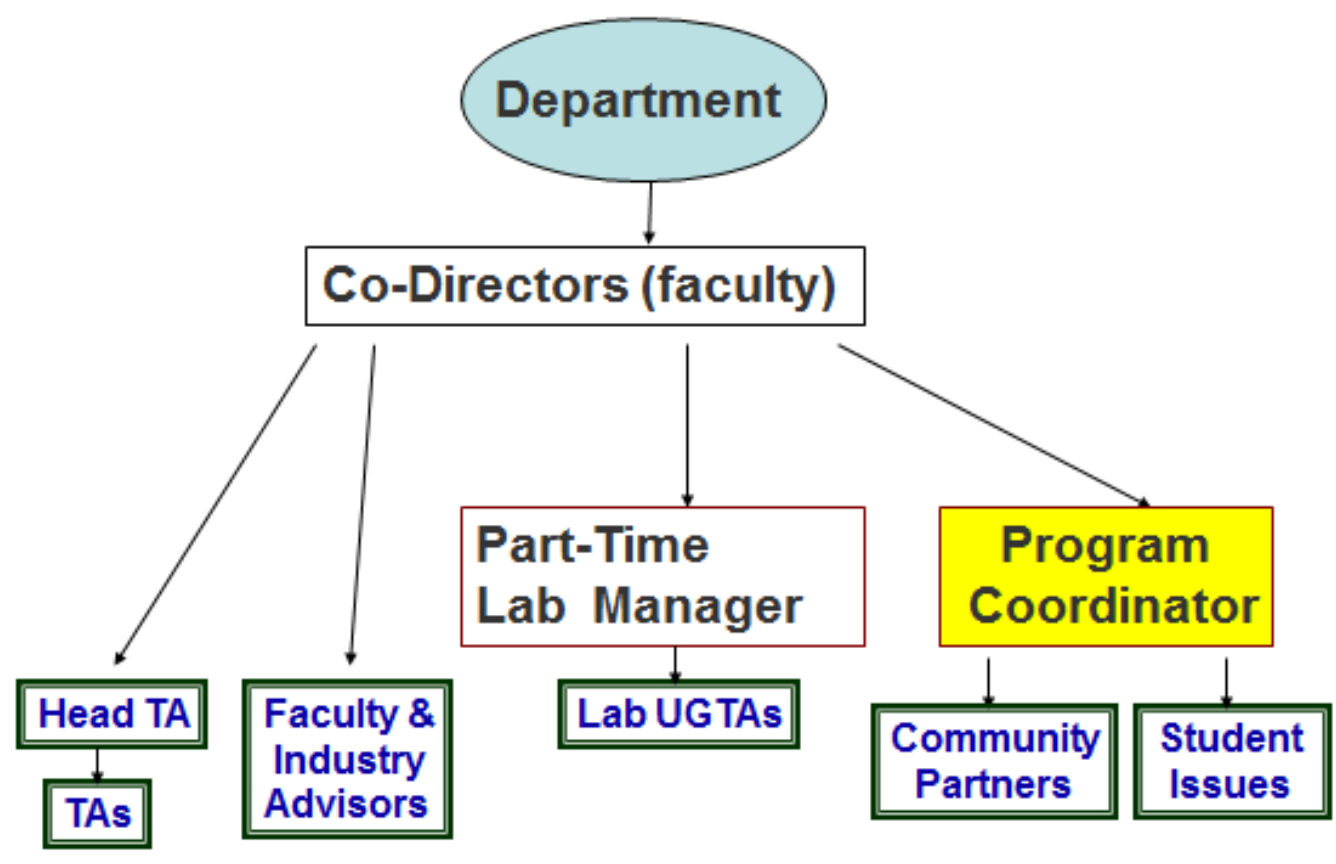

FIGURE 6

EARLY EPICS PURDUE ORGANIZATION

Another position that was added was a lab manager. Dean Leah Jamieson once describe the EPICS labs as a technological sandbox, which is an apt description, as our labs have diverse equipment such as high speed electronics, mechanical tools, posthole diggers, and shovels. We support a wide range of technologies. The lab manager in the early days was a graduate assistant. As the program grew to over 200 students, a full time lab manager position was created. This position further evolved to a half-time IT support, shared with the college, and a full time lab manager to support 400+ students each semester.

Graduate teaching assistants (TA) were used to support the teams and one half-time TA supported three lab sections. One of the TAs was designated as a head TA and assisted in the organization and training of the TAs.

For most of the time in EPICS, there have been two directors. Prof. Jamieson became the first Director when EPICS became a separate academic program in 2003. She also served as an associate dean for undergraduate education and during this time a full time staff position was created as an Academic Administrator to help with the management of the program. When Prof. Jamieson became dean of engineering, Prof. Oakes became Director with a $50 \%$ faculty appointment in EPICS. Subsequently, Dr. Carla Zoltowski, who served as the Academic Administrator (full time instructional staff position) became a co-director. As the program grew, a secretarial position was added and serves as the frontline contact with the students. The current organizational is shown in Figure 7 and includes staff who are dedicated to the dissemination of EPICS through the University Consortium as well as the K12 initiatives. The staff and faculty associated with the Purdue courses and university dissemination are funded by the university. The K12 work is funded through grants. 


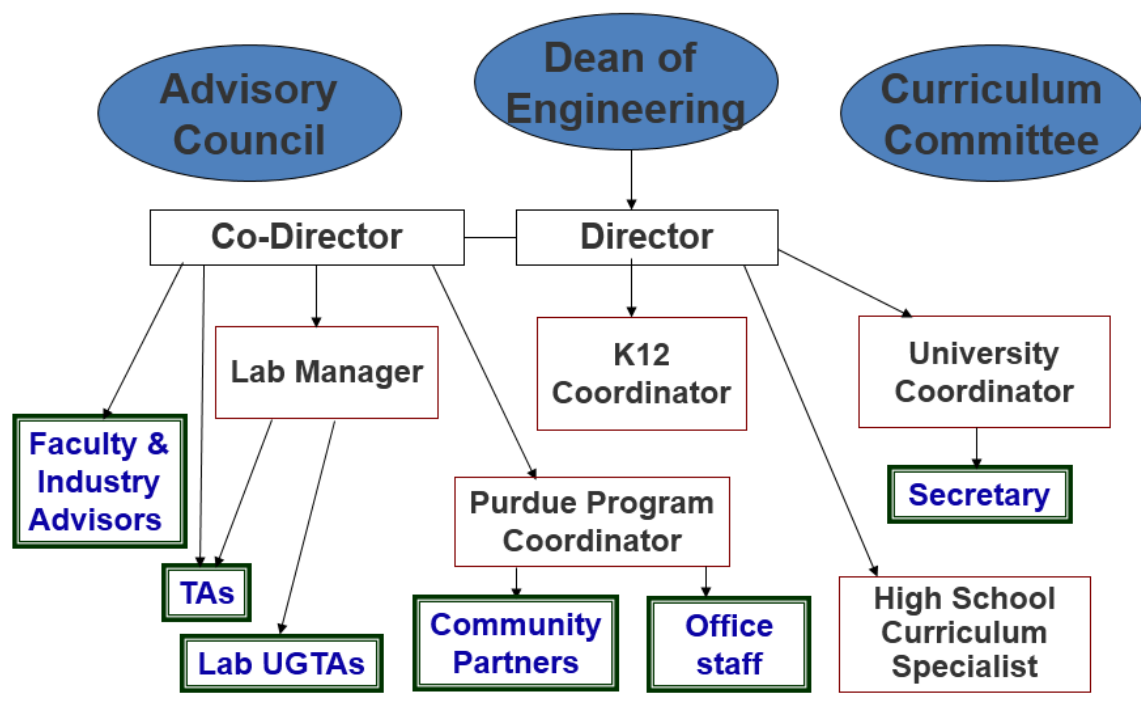

FIGURE 7

Current EPICS ORganization AT PuRdue

\section{Example Projects}

Table 2 provides examples of projects. A full description of the Purdue teams can be found at https://engineering.purdue.edu/EPICS/Projects/Teams. For examples of teams at other EPICS Universities, see the EPICS University website at: https://engineering.purdue.edu/EPICSU/Projects

TABLE 2. ACTIVE PROJECTS AND THEIR DESCRIPTIONS

\begin{tabular}{|l|l|l|l|}
\hline Team Name & Description & Partners & Majors \\
\hline Camp Riley & $\begin{array}{l}\text { The mission of the team to make Bradford } \\
\text { Woods, which host camps for kids with } \\
\text { disabilities like Camp Riley, more accessible. } \\
\text { Active projects include an accessible trail, } \\
\text { acoustic analysis of the sports pavilion, and a } \\
\text { sailboat control system. }\end{array}$ & $\begin{array}{l}\text { Camp Riley, Bradford } \\
\text { Woods, CHAMP Camp }\end{array}$ & $\begin{array}{l}\text { AcE, CE, CEM, } \\
\text { EE, IE, ME, IE, } \\
\text { HS, SLHS }\end{array}$ \\
\hline $\begin{array}{l}\text { Cellular } \\
\text { Engineering } \\
\text { Demonstrations } \\
\text { CED) }\end{array}$ & $\begin{array}{l}\text { The mission is to design and create interactive } \\
\text { models of living cells to engage young children. } \\
\text { The goal is to teach individuals ages 10 and up } \\
\text { about forces that allow our cells to hear, grow, } \\
\text { and touch. }\end{array}$ & $\begin{array}{l}\text { Indiana Children's } \\
\text { Museum. }\end{array}$ & $\begin{array}{l}\text { BME, Biology, } \\
\text { Education, EE, } \\
\text { CmpE, ME }\end{array}$ \\
\hline $\begin{array}{l}\text { Columbian Park } \\
\text { Zoo (ZOO) }\end{array}$ & $\begin{array}{l}\text { Design educational materials to be used by the } \\
\text { Columbian Park Zoo. }\end{array}$ & Columbian Park Zoo & $\begin{array}{l}\text { AS, ABE, } \\
\text { CmpE, EDU, } \\
\text { EE, IE, ME, CE }\end{array}$ \\
\hline
\end{tabular}




\begin{tabular}{|l|l|l|l|}
\hline $\begin{array}{l}\text { Database and } \\
\text { Innovative } \\
\text { Software for the } \\
\begin{array}{l}\text { Community } \\
\text { (DISC) }\end{array}\end{array}$ & $\begin{array}{l}\text { The mission is to create scalable data-centric } \\
\text { applications meant to track and organize project } \\
\text { partners' information. There is a focus on } \\
\text { remotely accessible tools that are full function } \\
\text { and easy to use. A lot of the current projects use } \\
\text { net and databases, but there are also python, } \\
\text { HTML, CSS, and other technologies. }\end{array}$ & $\begin{array}{l}\text { Day Break Rotary Club, } \\
\text { Earl Park Public Library, } \\
\text { Lafayette Crisis Center }\end{array}$ & $\begin{array}{l}\text { CmpE, CS, CIT, } \\
\text { COMM, EE, IE }\end{array}$ \\
\hline $\begin{array}{l}\text { Environmental } \\
\text { Improvement } \\
\text { Initiative (EII) }\end{array}$ & $\begin{array}{l}\text { This team will encourage students to develop } \\
\text { sustainable projects within the community and the } \\
\text { University. Current projects are Flint, MI street } \\
\text { lights, Purdue wastewater, LEED and History of } \\
\text { Technology: Implications for Sustainability }\end{array}$ & $\begin{array}{l}\text { Purdue University Office } \\
\text { of Sustainability, } \\
\text { Krannert School of } \\
\text { Management, City of } \\
\text { Flint, Michigan }\end{array}$ & $\begin{array}{l}\text { CE, IE, EEE, ES, } \\
\text { LA, MGMT }\end{array}$ \\
\hline $\begin{array}{l}\text { Global Alternative } \\
\text { Power Solutions } \\
\text { (GAPS) }\end{array}$ & $\begin{array}{l}\text { Developing alternative energy solutions to } \\
\text { provide power to remote rural villages and } \\
\text { underserved urban communities in Colombia } \\
\text { through collaborations with Colombian } \\
\text { universities, communities and industries. }\end{array}$ & $\begin{array}{l}\text { University of Antioquia, } \\
\text { Medellin, Colombia }\end{array}$ & $\begin{array}{l}\text { EE, CmpE, EE, } \\
\text { EEE, IE, ME, } \\
\text { MGMT, LA, } \\
\text { EDU, Physics, } \\
\text { Spanish }\end{array}$ \\
\hline $\begin{array}{l}\text { Greater Lafayette } \\
\text { Area Special } \\
\text { Services (GLASS) }\end{array}$ & $\begin{array}{l}\text { Develop technological solutions which enable } \\
\text { tudents with disabilities aged 3-21 to function } \\
\text { more independently and enjoy a better quality of } \\
\text { life. }\end{array}$ & $\begin{array}{l}\text { Greater Lafayette Area } \\
\text { Special Services } \\
\text { (GLASS) }\end{array}$ & $\begin{array}{l}\text { CmpE, EE, IE, } \\
\text { ME, MGMT, } \\
\text { Special Ed, } \\
\text { SLHS }\end{array}$ \\
\hline
\end{tabular}

Key: $\mathrm{AcE}=$ Acoustical Engineering; $\mathrm{ABE}=$ Agricultural and Biological Engineering; $\mathrm{AS}=$ Animal Science; $\mathrm{BME}$ $=$ Biomedical Engineering; $\mathrm{CE}=$ Civil Engineering; $\mathrm{COMM}=$ Communications; $\mathrm{CmpE}=$ Computer Engineering; $\mathrm{CS}$ = Computer Science; CIT = Computer Information Technology; CEM = Construction Engineering Management; $\mathrm{EDU}=$ Education $; \mathrm{EE}=$ Electrical Engineering; $\mathrm{EEE}=$ Environmental and Ecological Engineering; $\mathrm{ES}=$ Environmental Science; HS = Health Science; IE = Industrial Engineering; LA = Liberal Arts; ME = Mechanical Engineering; MGMT = Management; Special Ed = Special Education; SLHS = Speech, Language, and Hearing Sciences.

\section{Programmatic Assessment}

Programmatic assessment has been an important part of the development of the EPICS program and takes on many forms. As a course at Purdue, course evaluations are conducted each semester. EPICS participates in the traditional summative course assessments and supplements with customized questions to probe student satisfaction, learning, project success and community impact. Course assessments show a high level of satisfaction with students as shown in Figure 8. 


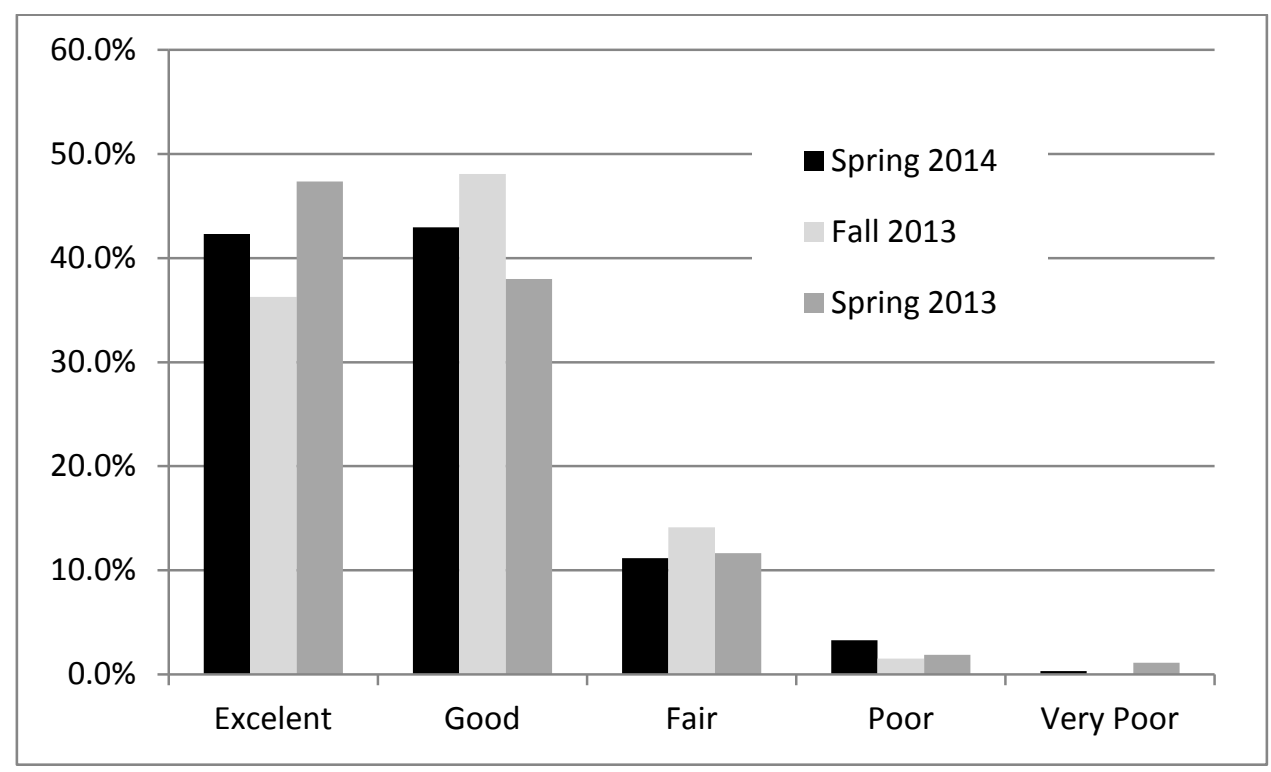

FIGURE 8

STUDENT SATISFACTION SURVEY

EPICS is an elective course and another measure of student satisfaction is enrollment and reenrollment. The EPICS model is designed for students to participate in multiple semesters to allow projects to span multiple semesters and support long-term partnerships. Figure 9 shows enrollment figures from 11 semesters as well as the number of students who returned each semester.

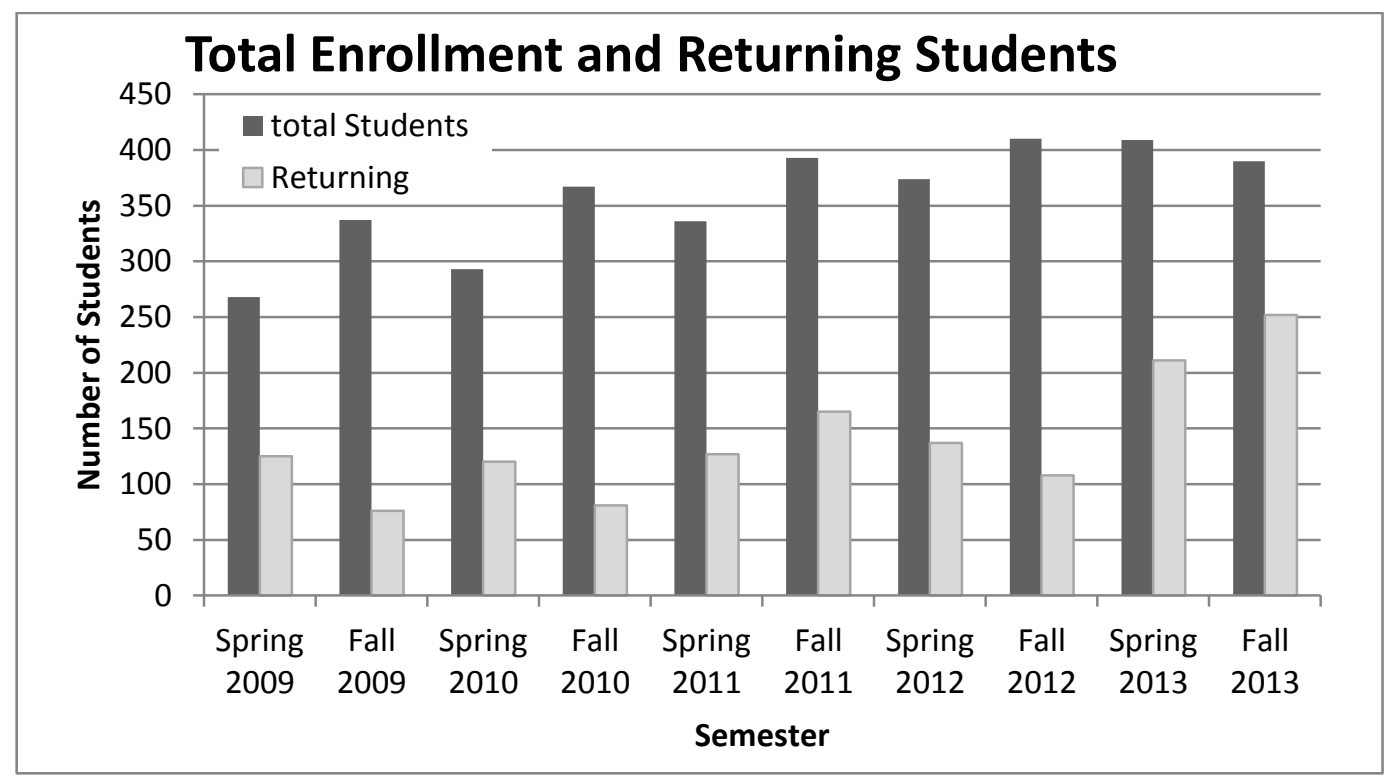

FIGURE 9

OVERALL ENROLLMENT IN EPICS AND RETURNING STUDENTS 
From the early days in EPICS, the course assessments have contained Likert-scale and openended questions that probed attributes that aligned with the ABET EC2000 criteria. One such question asked, "What are the three most valuable things you have learned from being a part of the EPICS program? " Coyle, Jamieson, and Oakes (2005) ${ }^{13}$ reported that a high percentage of students indicated that they developed skills ranging from technical skills to the professional skills including teamwork and leadership, communication, project management, and others (Table 3). Assessments since then have shown similar trends. Data from the 2013/14 academic year shows that communication and teamwork remained frequently reported (Table 4). More students talked specifically about Design in general and the Human-Centered Design approach taught within EPICS than in 2005 and were given separate categories. This reflects the emphasis on design and the move to teaching a specific human-centered design process. The reduction in teamwork from 2005 is partially accounted for with engineering shifting to team-based learning environments for all first-year students and across other engineering courses. Students receive formal team training in other courses and may not perceive EPICS as unique in that regard. While still a major topic of student development, other topics have moved into the top three for student such as design and human-centered design. It was interesting that a separate theme about multidisciplinary teaming and appreciation of diverse teams emerged. EPICS has become more multidisciplinary with more than 70 majors participating in some years. It is significant that students identify this as a learning outcome.

TABLE 3

\section{STUDENT RESPONSES TO THE QUESTION: WHAT ARE THE THREE MOST VALUABLE THINGS YOU HAVE LEARNED FROM BEING A PART OF THE EPICS PROGRAM ${ }^{10}$}

\begin{tabular}{|l|l|}
\hline Categories of Responses (with representative variations of comments) & $\begin{array}{l}\text { Total Number of Student } \\
\text { Responses }\end{array}$ \\
\hline Teamwork (teamwork, working with others, cooperation, accountability) & 1751 \\
\hline Leadership (leadership, responsibility, motivating self and others, taking initiative) & 534 \\
\hline $\begin{array}{l}\text { Communication (communication skills, presentation skills, public speaking, report } \\
\text { writing, communicating with clients) }\end{array}$ & 1008 \\
\hline $\begin{array}{l}\text { Organization and Planning (organization, project planning, time management, } \\
\text { meeting deadlines and timelines, goal setting) }\end{array}$ & 793 \\
\hline $\begin{array}{l}\text { Technical Skills (technical expertise, programming, design process, testing, } \\
\text { technical procedures) }\end{array}$ & 754 \\
\hline $\begin{array}{l}\text { Real World Experience (real applications, realistic view of working world, } \\
\text { experience for real life) }\end{array}$ & 222 \\
\hline Customer Awareness (customer needs, customer support) & 174 \\
\hline $\begin{array}{l}\text { Community Awareness (community needs, contribution to the community, value of } \\
\text { service) }\end{array}$ & 155 \\
\hline Total Number of Respondents & 2044 \\
\hline
\end{tabular}




\section{TABLE 4 \\ STUDENT RESPONSES TO THE QUESTION: WHAT ARE THE THREE MOST VALUABLE THINGS YOU HAVE LEARNED FROM BEING A PART OF THE EPICS PROGRAM? FROM THE 2013-14 ACADEMIC YEAR}

\begin{tabular}{|l|l|}
\hline Categories of Responses (with representative variations of comments) & $\begin{array}{l}\text { Total Number of } \\
\text { Student Responses }\end{array}$ \\
\hline Teamwork (teamwork, working with others, cooperation, $)$ & 149 \\
\hline $\begin{array}{l}\text { Communication (communication skills, presentation skills, public speaking, report } \\
\text { writing, documentation communicating with clients) }\end{array}$ & 117 \\
\hline Design (Design process, iteration, prototyping, testing decisions) & 87 \\
\hline $\begin{array}{l}\text { Human Centered Design (Importance of stakeholders in design, using prototypes to } \\
\text { communicate) }\end{array}$ & 66 \\
\hline $\begin{array}{l}\text { Experience, Professional Preparation (experience with real projects, real experience, } \\
\text { preparation for career) }\end{array}$ & 52 \\
\hline Leadership (leadership, responsibility, motivating self and others, taking initiative) & 51 \\
\hline $\begin{array}{l}\text { Multidisciplinary And Diverse Teams (working with diverse people/teams, learning } \\
\text { from different disciplines) }\end{array}$ & 46 \\
\hline Project Management, (getting tasks done in steps, planning, meeting deadlines) & 40 \\
\hline $\begin{array}{l}\text { Technical Skills (technical expertise, programming, technical procedures, disciplinary } \\
\text { skills) }\end{array}$ & 31 \\
\hline Ethics (importance of ethics, applying ethics) & 22 \\
\hline $\begin{array}{l}\text { Community (Impact on community, applying discipline to meet community needs, } \\
\text { community service) }\end{array}$ & 22 \\
\hline Total Number of Respondents & 311 \\
\hline
\end{tabular}

To further probe student learning and experiences, research and evaluation methods are used to focus on specific areas. An example was a study done to explore the impact of the EPICS experience after students graduate and enter industry. As noted earlier, the original purpose of EPICS was to prepare students for success and even leadership in industry. To explore the program's impact, an alumni survey was developed and is described by Cummings, Huff, Zoltowski, and Oakes (ASEE 2013). The results of the survey showed that EPICS helped prepare students for the workplace. For example, more than $80 \%$ of respondents cited EPICS preparing them to "some extent" to "very large extent" for the workplace (Figure 10). 


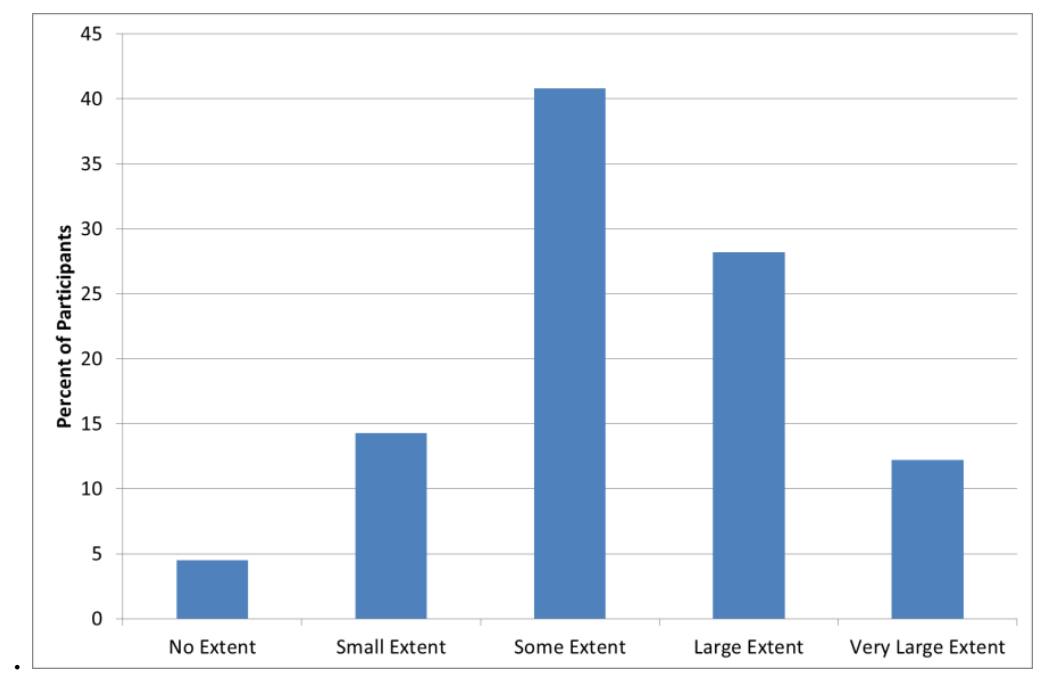

FIGURE 10

EPICS' CONTRIBUTION TO PARTICIPANTS' PREPAREDNESS FOR THE WORKPLACE. ${ }^{7}$

The survey also explored how EPICS and the service-learning context impacted their view of engineering. More than $80 \%$ of respondents indicated EPICS had at least "some extent" to a "very large extent" of in recognizing engineering as benefitting society (Figure 11).

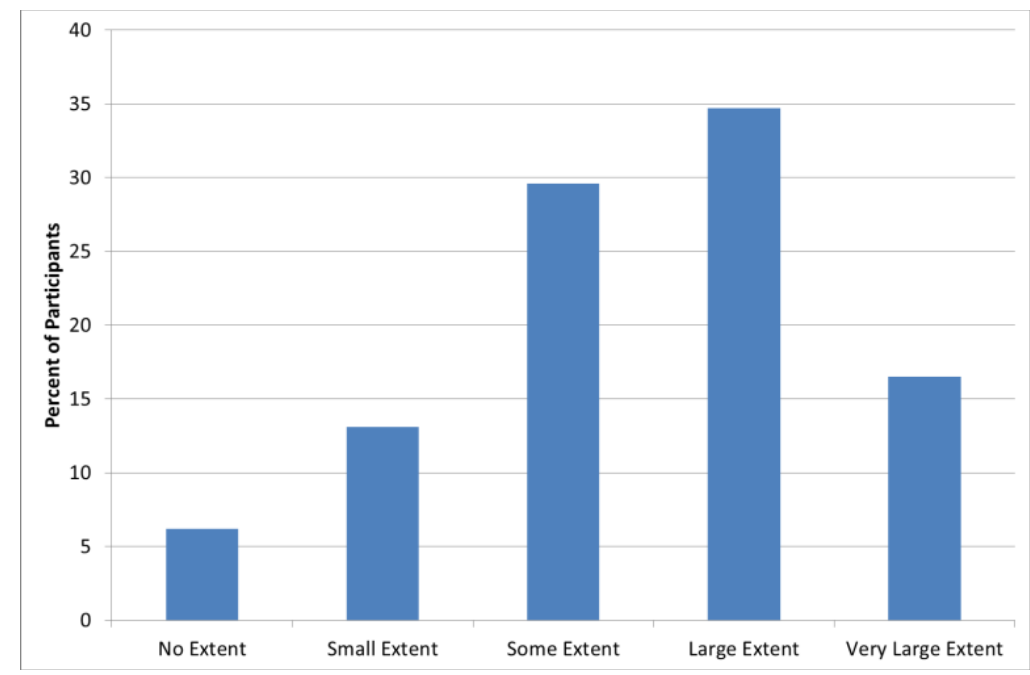

FIGURE 11

EPICS' CONTRIBUTION ON PARTICIPANTS' APPRECIATION FOR ENGINEERING AS BENEFITTING SOCIETY $^{7}$

Another question probed their desire to be active in the local community. $61 \%$ reported EPICS's contribution from "some extent" to a "very large extent" (Figure 12). While lower than the preparation for work questions, it was still significant. Many of the students reported that they were already committed to being active and that is what drew them to the program in the first place. These students did not attribute EPICS to their desire to serve in the community. 


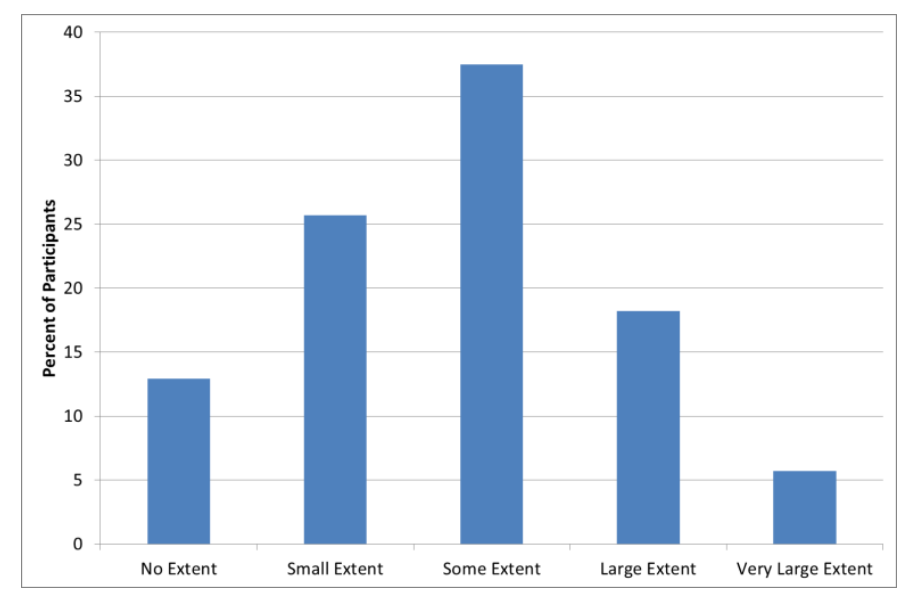

FIGURE 12

EPICS' CONTRIBUTION ON PARTICIPANTS' DESIRE TO PLAY AN ACTIVE ROLE IN THEIR LOCAL COMMUNITY $^{7}$

Follow-up interviews were conducted with 27 purposefully sampled alumni based on the interview questions. This process was described in Huff et al. ${ }^{14}$. These interviews resulted in data that further supported the findings that graduates found the EPICS experience valuable preparation for their careers and their understanding of design ${ }^{12}$. A complete analysis of the interview and survey data is being prepared for a future manuscript. Examples of the quotes from the interviewed showed an appreciation of EPICS as preparation for their professional experience:

And it's very similar to industry. What we do here is very similar to what you guys do; it's just that the customers are different, I think there is more of a customer focus in what you do, but that's because the job that you do is more integrated and in a much more smaller scale. There's more division of labor out in industry. You know, managers realize their cost and their structure within their company, so they split it out and they divide it up so it's easier for the people that are doing a certain job to do it faster and, you know, basically achieve division of labor scale. That's what we do here.

Their view of community engagement was also impacted:

So, I was just looking at it like as a student who can learn how to use my skills or whatever so I can use them in the community, and I thought EPICS would help me do that. That's how I was thinking as a student. And so now that, you know, I'm alumni or whatever, I reflect back and look back, and see that I learned that and that helped me for, you know, my job but not just my job [but also] some volunteer activities that I am in now.

The context of EPICS aligns with research on diversity and indicates that EPICS and servicelearning can be a means of increasing participation of underrepresented populations. A study focused on the experiences of women in EPICS ${ }^{15}$. In this study, 20 semesters of enrollment data 
were examined from the two majors representing the largest percent of EPICS students, Mechanical and Electrical and Computer Engineering. These data showed that EPICS attracted female students from these majors at more than $170 \%$ of the percent within their respective majors as seen in Figure 13. Interviews of the women showed that they were attracted by the opportunity to gain experience as engineers which they described as "hands-on", "real world/life" or "design" experience. They valued this experience as a way to develop their own skills set and be better prepared for prospective employers. Some of the women specifically cited the community context but most indicated that they were participating to gain experience. The majority, however, began with the community context when they were asked how they would describe the program to someone who was not familiar with it ${ }^{11}$.

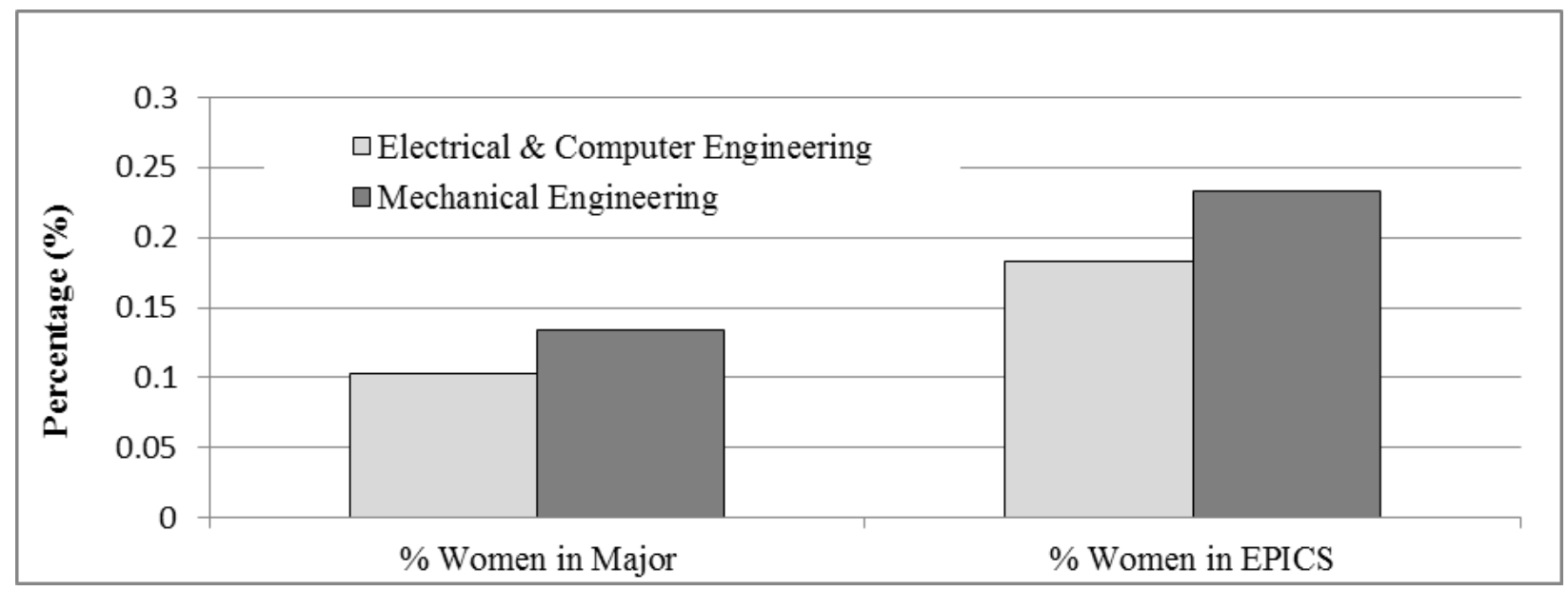

FIGURE 13

PERCENT OF WOMEN ENROLLED IN EPICS FROM ECE AND ME ${ }^{12}$

The community impact has been measured in several ways. The first is the number of delivered projects, which has exceeded 300 within the local community. Satisfaction surveys of community partners has shown a high level of satisfaction with $90 \%$ being satisfied with their experience 7 . More recently, the program has moved away from surveys and has direct discussions with the partners. A staff member not directly associated with the student team meets with the partners to discuss progress and satisfaction with the program. A metric of success has been the sustaining partnerships. Seventeen of the current partners have been with the program for more than a decade. Long-term partnership are key to the success of EPICS and the state of the partnerships is something that is managed closely.

\section{Best Practices and Success Criteria for Replicating EPICS}

In order to understand best practices and success criteria, we used Knoster's academic managing complex change model to analyze 32 institutions that have adopted or begun to adopt a program that follows the EPICS model ${ }^{16}$. In his model, Knoster ${ }^{17}{ }^{18}$ identified six factors needed to manage complex change; they include: vision, consensus, skills, incentives, resources, and action plan. When all are present, change can occur. However, Table 4 below shows the negative effect missing factors on the change effort. Through this analysis we were able to identify key elements 
needed for successful dissemination of not only the EPICS model, but of other models of curricular change. The programs that included all of the elements were and remain thriving while many of the programs missing elements have either ceased or have declined. Those who have not included all of the elements may be at risk of not sustaining the innovations. Each of the programs that have ceased were missing one or more of the elements.

TABLE 4

MODEL FOR CHANGE: RESULTS WHEN FACTORS ARE MISSING

\begin{tabular}{|l|l|l|l|l|l|l|}
\hline Vision + & Consensus + & Skills + & Incentives + & Resources + & Action Plan & $=$ Change \\
\hline & Consensus + & Skills + & Incentives + & Resources + & Action Plan & $=$ Confusion \\
\hline Vision + & & Skills + & Incentives + & Resources + & Action Plan & $=$ Sabotage \\
\hline Vision + & Consensus + & & Incentives + & Resources + & Action Plan & $=$ Anxiety \\
\hline Vision + & Consensus + & Skills + & & Resources + & Action Plan & $=$ Resistance \\
\hline Vision + & Consensus + & Skills + & Incentives + & & Action Plan & $=$ Frustration \\
\hline Vision + & Consensus + & Skills + & Incentives + & Resources + & & $=$ Treadmill \\
\hline
\end{tabular}

Consistent themes for those programs that have been successful in implementing this model included having senior leadership and taking the time and effort to build consensus among colleagues through accepted academic structures. All of the programs that found ways to work around existing structures such as curriculum committees were at risk and declined or ceased. While these structures often slow innovation, the long-term benefits appear to outweigh the short term gains. Incentives were consistently correlated with appropriate teaching credit for the courses.

The examination of funding indicates that seed funding to start programs is not correlated with long-term program success. Programs that began on grants often had infrastructures that depended on external grants. Programs that began without grant funds were required to find institutional funds which contributed to the long-term sustainability. While some of the current programs remain dependent at least in part on grant or gifts from corporate, alumni and/or foundation partners' funds, the programs have grown with the ability of the local programs to secure such funding.

\section{Where to Start}

The purpose of this paper is to share the lessons learned, processes and materials developed over nearly two decades of the EPICS program. While we believe these lessons can be valuable across many other applications, we recognize that if you are looking to start a program, the size, scope and complexity may not fit your immediate needs. We did not start at this size and neither should you. When starting an EPICS or EPICS-like program, there are a few key concepts to keep in mind.

The first is that each combination of institution, students and community is unique. EPICS looks different at every institution. Leaders looking to start a program have to consider the stakeholders, institutional culture and constraints to set appropriate goals for their own program and leverage existing curricular structures when possible. Use institutional processes (e.g. curriculum committees) to establish your course or program within the curriculum. This may take time and effort but it will pay off in the long run. Each institution has different priorities, 
values and goals. Look to align your work with these institutional priorities to show the value added to your department, college and campus.

Start small enough to be successful. The Purdue EPICS Program started with Professors Leah Jamieson and Edward Coyle enlisting a small group of colleagues and 40 students who were all juniors and seniors in ECE. They were successful in their work and built upon it. Grow as you have the capacity to grow. Seek resources within the institution to support your growth as you show the value-added by your work. The assessment and project management materials presented in the paper and available on the EPICS websites can be used with any size or age program. Use existing tools and materials whenever possible when starting and adapt with permission as needed.

Select your initial partners and projects carefully and intentionally. Look for projects that have a high probability of success to build momentum and demonstrate success. Many successful programs have started with initial projects that were smaller in scope to demonstrate the concept and built upon those successes. Select partners that have people who understand what you are intending to do and will walk with you during initial successes and challenges. Treat them as respected partners, sharing your educational, project and community goals. Commit to these partners for an agreed upon time to establish credibility and patience if you run into initial challenges. Be honest and share your ideas and limitations with the partners before you begin the courses. Listen to them and they will teach you a great deal.

Make the students partners too. Like with the community partners, be honest with the students. They respond and respect us being honest that we are trying something new and meaningful. Students are seeking meaningful work and they will provide considerable grace to us for engaging them in that work. Assure them that is things go badly and it is not their fault, you will take care of them. They are often worried about their grades and assuring them can allow them to focus on the engagement work itself. Share the grading and assessment rubrics and materials with them and explain why you are assessing them in the manner you are to demonstrate that you are being transparent. Empower the students to be leaders and model lifelong learning. Students rise to meet challenges and let them be empowered to drive the projects. Act as a coach or advisor to the students. EPICS seeks to equip students for professional practice and providing empowered experiences is a key to doing so. We are continually amazed at what students can accomplish when empowered.

\section{CONCLUSION}

The EPICS model has proven to be effective as a curricular model to prepare students for a wide range of careers including those within traditional corporate engineering settings. It has also shown to be a means to develop and sustain long-term community partnerships that provide mutual benefit and significant community impact. While EPICS has seen significant success, both here at Purdue and at other institutions, it continues to evolve and develop. Lessons from other programs are routinely and systematically integrated into the program to increase the impact on student learning and the community. The model can also be adapted to create or improve community engagement programs, and many of the structures can be applied to other curricular and co-curricular programs as well (e.g., undergraduate research programs). Efforts to apply the model to settings such as EWB-USA chapters have begun and shown positive results to date. Also, EPICS has proven to be a means to increase diversity within engineering at the 
college and the pre-college levels. These characteristics are not unique to EPICS and are seen in other engagement programs such as EWB-USA.

We truly enjoy our work. While it seems daunting and even overwhelming at times, it is truly rewarding. Talking with alums about how it has impacted their careers and view of themselves and their profession is inspiring. Equally inspiring is seeing the impact our students make in the lives of others.

\section{ACKNOWLEDGEMENTS}

We wish to acknowledge the many people who have worked to make EPICS what it is today, including faculty, staff and industry partners, community and project partners, industrial sponsors and students. We wish to acknowledge Professors Leah Jamieson and Edward Coyle for their vision and dedication to create EPICS and develop it into a program at Purdue and a model that has been replicated to many other institutions. Our current and recent staff, Pam Brown, Maeve Drummond, James Huff, Andrew Pierce, Christine Benner, Tom Heck, Jean Trusedell, and Mari-Ellyn Brock, make our jobs easier. We also wish to acknowledge the administration of Purdue University their historical and continued support of the EPICS Program. 


\section{Appendix A: Individual Evaluation Rubric}

Team:

Student:

Week:

Course: Roles:

No. of semesters in EPICS:

Project(s): Major:

In the following box, list all of your significant contributions and learning since the beginning of the semester and where documentation of those can be found (add lines as necessary). Mark an " $X$ " under the grading criteria you think are applicable for each item:

\begin{tabular}{|c|c|c|c|c|c|c|}
\hline $\begin{array}{l}\text { Contribution/Learning (e.g., completed user } \\
\text { analysis, data analysis, DFMEA, or prototype, } \\
\text { programmed microprocessor; learned CATIA) }\end{array}$ & $\begin{array}{l}\text { Where documentation can be } \\
\text { found: (include page \#s if in } \\
\text { notebook and URLs if online) }\end{array}$ & 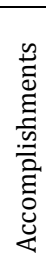 & $\begin{array}{l}\tilde{d} \\
\stackrel{d}{0} \\
\dot{D}\end{array}$ & 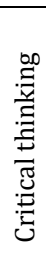 & 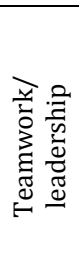 & 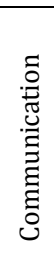 \\
\hline & & & & & & \\
\hline & & & & & & \\
\hline & & & & & & \\
\hline & & & & & & \\
\hline
\end{tabular}

In the following box, list contributions and learning planned for rest of semester (N/A for final submission)

\begin{tabular}{|l|l|}
\hline Contribution/Learning: & $\begin{array}{l}\text { To be completed by: ( ex: } \\
9 / 20 / 11)\end{array}$ \\
\hline & \\
\hline & \\
\hline & \\
\hline & \\
\hline
\end{tabular}

Directions: Students mark an "X" and Advisors/TAs mark an "O" in the appropriate box for each criterion. Each of the criterion should be evaluated considering the student's course level, major, semester in EPICS, and number of credits.

\begin{tabular}{|c|c|c|c|c|c|c|c|c|c|c|c|c|c|}
\hline & \multicolumn{3}{|c|}{ Excellent } & \multicolumn{3}{|c|}{ Good } & \multicolumn{3}{|c|}{ Adequate } & \multicolumn{3}{|c|}{ Low passing } & \multirow[b]{2}{*}{$\mathrm{F}$} \\
\hline & $\mathrm{A}+$ & A & A- & $\mathrm{B}+$ & B & B- & $\mathrm{C}+$ & $\mathrm{C}$ & C- & $\mathrm{D}+$ & D & D- & \\
\hline $\begin{array}{l}\text { Accomplishments: Individual } \\
\text { contributions to the project and impact on } \\
\text { design and/or deliverables. Understanding } \\
\text { of relevant discipline-specific issues } \\
\text { related to the project. Documentation of } \\
\text { individual work and incorporation into } \\
\text { project documentation. }\end{array}$ & & & & & & & & & & & & & \\
\hline $\begin{array}{l}\text { Process: Documented understanding the } \\
\text { processes inherent in design and an ability } \\
\text { to employ these processes in the } \\
\text { development of the project. }\end{array}$ & & & & & & & & & & & & & \\
\hline $\begin{array}{l}\text { Reflective/Critical Thinking: } \\
\text { Demonstrates ability to think critically } \\
\text { about many of the disciplinary, social, } \\
\text { ethical, personal, and interpersonal aspects } \\
\text { of the project, project partner, and their } \\
\text { relationships. }\end{array}$ & & & & & & & & & & & & & \\
\hline
\end{tabular}




$\begin{aligned} & \text { Teamwork/Leadership: Initiative and } \\ & \text { participation in class and group work. } \\ & \text { Works with and helps other team members, } \\ & \text { within and/or outside of formal team roles, } \\ & \text { to accomplish team goals. Lab and project } \\ & \text { meeting attendance. If applicable, } \\ & \text { leadership and fulfillment of } \\ & \text { responsibilities associated with team } \\ & \text { position. }\end{aligned}$
$\begin{aligned} & \text { Communication: Written and oral } \\ & \text { communication, both formally and } \\ & \text { informally, to all audiences: people } \\ & \text { familiar with project, and those who are } \\ & \text { not; people with both similar and different } \\ & \text { backgrounds; to teammates and to external } \\ & \text { people; to those who will be asked to } \\ & \text { continue your project in the future. }\end{aligned}$

\section{Students:}

Overall grade you believe you have earned to this point in the semester:

Why? Please include specific examples of "Excellent", "Good", "Adequate", or "Low Passing" (whichever corresponds to the grade you have given yourself) Accomplishments, Process, Reflective Thinking, Teamwork/Leadership and/or Communication in the box below. Please also include any additional information that was not reflected in the evidence you provided.

\section{Advisors/TA:}

Grade earned to this point in the semester:

Explanation for grade (in box): 
International Journal for Service Learning in Engineering Special Edition, pp. 1-32, Fall 2014

ISSN 1555-9033

\section{REFERENCES}

${ }^{1}$ Huff, J., Zoltowski, C., Oakes, W., and Adams, R., "Making Sense of Design: A Thematic Analysis of Alumni Perspectives", Proceedings of the 2013 ASEE Annual Conference, Atlanta, GA, June 2013

${ }^{2}$ Cummings, A., Huff, J., Oakes, W. and Zoltowski, C., “An Assessment Approach to Project-Based Service Learning", Proceedings of the 2013 ASEE Annual Conference, Atlanta, GA, June 2013

3 Matusovich, Holly M. , William Oakes, and Carla B. Zoltowski, "Why Women Choose Service-Learning: Seeking and Finding Engineering-Related Experiences", International Journal of Engineering Education, Vol. 29, No. 2, 2013, pp. 388-402.

${ }^{4}$ http://products.gallup.com/168857/gallup-purdue-index-inaugural-national-report.aspx, Accessed 10/14/2014.

${ }^{5}$ Edward J. Coyle, Leah H. Jamieson, and Larry S. Sommers, "EPICS: A Model for Integrating Service-Learning into the Engineering Curriculum",Michigan Journal of Community Service Learning, Vol. 4, Fall 1997, pp. 81-89.

${ }^{6}$ Nation, Sarah, Oakes, William, Bailey, Lowell, Heinzen, Jill, "Conversion of Collegiate EPICS to a K-12 Program", Proceedings of the Frontiers in Education Conference, Indianapolis, IN, October 2005

${ }^{7}$ Thompson, Michael, Pamela Turner and William Oakes, "Teaching Engineering In High School Using ServiceLearning: The EPICS Model", Proceedings of the 2008 ASEE Annual Conference, Pittsburgh, PA, June 2008

${ }^{8}$ Oakes, William, Zoltowski, Carla B., Cardella, Monica E., and Horton, William Travis, "Integration of a FirstYear Learning Community with a Vertically Integrated Design Program", Proceedings of the 2014 ASEE Annual Conference, Indianapolis, IN, June 2014

${ }^{9}$ Ash, S. L., Clayton, P. H., \& Moses, M. G. (2009). Learning through critical reflection: A tutorial for servicelearning students (instructor version). (pp. 4-5 through 4-7)

${ }^{10}$ Cummings, A., Huff, J., Oakes, W. and Zoltowski, C., “An Assessment Approach to Project-Based Service Learning", Proceedings of the 2013 ASEE Annual Conference, Atlanta, GA, June 2013

${ }^{11}$ Jamieson, Leah H, Oakes, William C. and Coyle, Edward J, EPICS: Documenting Service-Learning To Meet EC 2000, , Proceedings of the 2001 ASEE/IEEE Frontiers in Education Conference, Reno, NV, October 2001.

${ }^{12}$ Zoltowski, C ., Oakes, W., and Cardella, M., "Students' Ways of Experiencing Human-Centered Design”, Journal of Engineering Education, Vol. 101, No. 1, January 2012, pp. 28-59

${ }^{13}$ Coyle, Edward J., Jamieson, Leah H., Oakes, William C, "EPICS: Engineering Projects in Community Service", International Journal of Engineering Education Vol. 21, No. 1, Feb. 2005, pp. 139-150.

${ }^{14}$ Huff, J., Zoltowski, C., Oakes, W., and Adams, R., "Making Sense of Design: A Thematic Analysis of Alumni Perspectives", Proceedings of the 2013 ASEE Annual Conference, Atlanta, GA, June 2013 
International Journal for Service Learning in Engineering Special Edition, pp. 1-32, Fall 2014

ISSN 1555-9033

${ }^{15}$ Matusovich, Holly M. , William Oakes, and Carla B. Zoltowski, "Why Women Choose Service-Learning: Seeking and Finding Engineering-Related Experiences", International Journal of Engineering Education, Vol. 29, No. 2, 2013, pp. 388-402.

${ }^{16}$ Oakes, W.C., Zoltowski, C.B., Drummond, M,(2014) "Dissemination of Community Engagement in Engineering and Computing", Proceedings of the Frontiers in Education Conference, Madrid, Spain,

${ }^{17}$ Knoster, T. (1991). Presentation in TASH Conference, Washington, DC.

${ }^{18}$ Knoster, T., Villa, R., \& Thousand, J. (2000). A framework for thinking about systems change. In R. Villa \& J. Thousand (Eds.), Restructuring for caring and effective education: Piecing the puzzle together (pp. 93-128). Paul $\mathrm{H}$. Brookes Publishing Co, Baltimore, MD. 